\title{
PENYIMPANGAN BAHASA PUISI DALAM \\ SASTRA SIBER
}

\author{
Nani Solihati \\ Program Studi Pendidikan Bahasa dan Sastra Indonesia \\ Fakultas Keguruan Ilmu Pendidikan-Universitas Muhammadiyah Prof. Dr. Hamka
}

\begin{abstract}
Abstrak
Penelitian ini bertujuan untuk mengetahui penyimpangan bahasa puisi dalam sastra siber. Untuk mengetahui hal tersebut, maka penelitian ini menggunakan metode deskriptif kualitatif. Hasil penelitian ini menunjukkan bahwa lima puisi yang terdapat dalam sastra siber dengan data sampel yang diambil dari laman sastradigital.com melakukan penyimpangan bahasa. Kelima puisi itu ialah puisi Kidung Rindu Bagi Perempuanku karya Alif Raung Firdaus melakukan penyimpangan sintaksis, penyimpangan historis, dan penyimpangan leksikal, puisi Aek Sarulla karya Mangasi Sihombing melakukan penyimpangan dialek dan penyimpangan historis, puisi mimpi dari Milimeter Jarak Sepi karya Ujianto Sadewamelakukan penyimpangan sintaksis dan penyimpangan semantis,puisi Bukan Kopi Hongaria karya Cecep Samsul Harimelakukan penyimpangan semantis dan penyimpangan dialek, dan puisi Di Jembatan Pasupati karya Fajar M. Fitrah melakukan penyimpangan sintaksis, penyimpangan grafologis, penyimpangan register, dan penyimpangan dialek.
\end{abstract}

Kata Kunci: Penyimpangan Bahasa, Puisi, Sastra Digital.

\begin{abstract}
This study aims to determine linguistic deviation in the poetic of cyber literature. To determine this, the research uses descriptive qualitative method. The results of this study indicate that the five poems contained in the cyber literature with sample data taken from websites sastradigital.com doing linguistic deviation. It is the fifth poem Kidung Rindu Bagi Perempuankun poetry by Alif Raung Firdaus doing Grammatical deviation, Deviation of historical period., andlexicaldeviation, Aek Sarullc poetry by Mangasi Sihombing doing Dialectical deviationand Deviation of historical period, Mimpi dari Milimeter jarak Sepia, poetry by Ujianto Sadewadoing Grammatical deviationand Semantic dcviation, Bukan Kopi Hongaria a poetry by Cecep Samsul Haridoing Semantic deviation andDialectical deviation, and Di Jembatan Pasupatia poetry by Fajar M. Fitrahdoing Grammatical deviation, Graphological deviation, Deviation of register, andDeviation of historical period.
\end{abstract}

Keywords: Linguistic Deviation, Poetry, Digital Literature.

\section{PENDAHULUAN}

Perkembangan sastra di Indonesia selalu ditandai dengan perubahan pola publikasi. Publikasi menjadi hal yang vital dalam upaya membumikan sastra. Sebab pada dasarnya, karya sastra hadir untuk dibaca, dinikmati, dan diambil hikmahnya.

Dalam hal publikasi, tentu saja
perkembangan teknologi mengambil peran
penting. Hal ini dapat dilihat pada pola
penulisan karya sastra. Ditinjau dari sudut
filologi, maka karya sastra pada awalnya hanya
hadir di daun lontar, bambu, dan juga batu-
batuan. Tentu saja hal semacam ini
menyulitkan karya sastra tersebut menyebar
lantaran penggandaan terhadap naskah pada

Dalam hal publikasi, tentu saja penting. Hal ini dapat dilihat pada pola penulisan karya sastra. Ditinjau dari sudut filologi, maka karya sastra pada awalnya hanya hadir di daun lontar, bambu, dan juga batubatuan. Tentu saja hal semacam ini lantaran penggandaan terhadap naskah pada 
benda-benda tersebut memakan waktu cukup lama.

Namun hadirnya mesin cetak memungkinkan karya tersebut menyebar. Pola penulisan pun mulai berubah, penulis mulai menulis di atas kertas dengan pena, sebagian penulis bahkan langsung menulis karya sastra dengan mesin tik. Karya tersebut kemudian diketik kembali dengan komputer dan lalu dimasukkan ke dalam mesin cetak. Dalam hitungan waktu yang tak seberapa lama. Ratusan bahkan ribuan karya dengan mudah digandakan. Demikian, pada akhirnya karya sastra menemukan tempat di masyarakat.

Di era ini pemerintahan Belanda membentuk Commissie voor de Volkslectuur yang dibentuk 14 September1908 yang kemudian berubah nama menjadi Balai Pustaka pada 22 September 1917. Kualitas karya sastra yang lahir dari penerbit Balai Pustaka ini kemudian memunculkan angkatan sastra baru yang disebut dengan angkatan Balai Pustaka, meski sebagian ada yang menyebutnya dengan angkatan 20. Di antara karya yang diterbitkan oleh Balai Pustaka adalah Arab dan Sengsara karya Merari Siregar. Marah Roesli dengan novelnya Siti Nurbaya dan Abdul Muis dengan novelnya Salab Asuban.

Selanjutnya, angkatan 30 atau Pujangga Baru memunculkan perkembangan lain, selain menerbitkan buku seperti terbitnya karya Armijn Pane dengan novelnya yang bejudul Belenggu, terbit juga novel karya Sutan Takdir Alisyahbana dengan karyanya yang berjudul Layar Terkembang dan Buya Hamka lewat novelnya Di Bawab lindungan Ka'bah dan Tenggelamnya Kapal Van Der Wijck. Angkatan ini juga memunculkan majalah sebagai media lainnya untuk menghadirkan karya sastra, majalah itu di antaranya adalah Poedjangga Bane, Wasita dan Pusara.

Pola pengembangan publikasi semakin berubah arah pada angkatan 45. Meski buku tetap menjadi bagian tak terpisahkan dari karya sastra, ada kecendrungan lain yang membuat karya sastra di Indonesia semakin manabalkan diri di tengah masyarakat. Misalnya majalahmajalah seperti seperti Mimbar Indonesia, Zenith, Kisah dan Sastra. Di sini, selain karya sastnra yang muncul, tulisan-tulisan kritis tentang karya sastra pun mewarnai khazanah kesastraan Indonesia, hal ini terlihat dari tulisan HB. Jassin.

Masuk ke dalam angkatan '66. Pada angkatan ini publikasi di majalah semakin sering dilakukan dan bahkan memberi peranan yang penting dalam perkembangan sastra Indonesia. Hal ini dapat dilihat dari majalah Horison yang terbit pertama kali pada tahun 1966. Sejak terbit, majalah sastra ini memiliki wibawa yang tinggi di hadapan para pembaca karya sastra. Ketika itu, siapapun yang ingin mengenal sastra Indonesia, entah itu penyair, cerpenis, eseis/kritikus dan pengamat sastra pada umumnya, belum lengkap jika belum membaca Horison. Selain itu, anggapan lain yang muncul adalah seorang penulis karya sastra belumah sah jika tidak dimuat di Horison. Dari sini, majalah Horison memiliki kesan yang merepresentasikan kualitas karya sastra. Di antara angkatan '66 yang aktif menulis di Horison adalah Taufiq Ismail, Umar Kayam, Goenawan Mohamad, Budi Darma, Hamsad Rangkuti, Putu Wijaya, dan lain-lain. Era ini sering pula disebut sebagai era majalah sastra.

Namun arah perkembangan publikasi karya sastra semakin berubah. Terhitung masuk ketahun 80-an. Karya sastra lebih banyak muncul di koran-koran. Ini diindikasikan dengan banyaknya rubrik sastra di berbagai koran, rubrik-rubrik tersebut tidak lagi hanya memuat puisi dan cerpen, namun juga di antaranya memuat novel (terbit berkala), dan esai sastra. Koran-koran yang memuat karya sastra di antaranya Kompas, Suara Karya, Sinar Harapan, dan Media Indonesia. Namun demikian, hadirnya karya sastra di koran biasanya hanya sehari dalam sepekan. Itupun hadir di hari Ahad atau Sabtu 
saja. Akan tetapi, fakta tersebut tidak menggoyahkan peran koran dalam memberi arah sastra Indonesia hal ini dikarenakan pada akhirnya koran pun menjadi suatu tempat dalam melegitimasi seorang sastrawan.

Dasawarsa semacam ini terus berjalan sampai kini, peran koran Kompas, Jawa Pos, Republika, Sinar Harapan, Suara Pembaruan, dan beberapa koran baru seperti Seputar Indonesia bahkan masih secara reguler menerbitkan karya sastra setiap akhir pekan. Di beberapa daerah, koran-koran daerah menerbitkan karya sastra dalam waktu yang sama sebut saja, Surabaya Post, Lampung Post, Padang Ekspres, dan lain-lain. Berkembangnya sastra di koran kini telah mematahkan dominasi sastra majalah. Sehingga akhirnya, perkembangan semacam ini lebih disebut sebagai sastra koran.

Namun, kini majalah dan koran pun harus berbagi. Adanya internet menjadi media publikasi lain yang membuat suatu karya sastra dapat dinikmati oleh khalayak. Jalan ini yang kemudian disambut baik oleh penulis sastra Indonesia. Muncullah kemudian dengan istilah sastra siber. Sastra siber secara definitif disampaikan oleh Enraswara sebagai sebuah aktivitas sastra yang memanfaatkan media komputer atau internet (2006:182).

Namun kemunculan ini bukan berarti tidak menimbulkan masalah. Masalah lain yang muncul adalah, mengenai kualitas karya sastra siber tersebut. Sebagian bahkan mencibir sebagai sastra sampah, seperti yang diungkapkan oleh Ahmadun Yosi Herfanda (2014). Menurutnya, hal tersebut lebih dikarenakan bahwa karya tersebut tidak melewati seleksi kontrol yang baik dibandingkan dengan koran ataupun majalah yang memang memiliki redaktur khusus untuk menilai suatu karya layak dimuat atau tidak.

Memang sebagian besar, penulis sastra yang gagal mempublikasikan karyanya di koran lantas mempublikasikannya di internet. Bahkan ada kecendrungan pemberontakan yang dilakukan oleh para penulis tersebut. Bahwa pada dasarnya suatu karya dilahirkan bukan untuk dihakimi dan dibunuh dengan cara keji, dalam hal ini tidak dibiarkan dibaca orang banyak. Maka dari itu, sastra siber berkembang pesat di awal 2000-an, bahkan kemudian membuat antologi buku Graffiti Gratitude pada 9 Mei 2001.

Kini perkembangan sastra siber semakin kompleks. Munculnya jejaring sosial seperti Facebook dan Twitter membuat fenomena baru dalam kesastraan Indonesia. Selain memunculkan diskusi hangat berkaitan dengan perkembangan sastra Indonesia seperti polemik plagiat yang dilakukan oleh Seno Gumira Ajidarma lewat cerpenya Dodolitdodolibret sampai pada polemik terhangat dengan munculnya buku 33 Tokoh Sastra Indonesia yang Berpengaruh. Jejaring sosial juga mewadahi penulis baru untuk mempublikasikan karyanya untuk dapat diberikan masukan secara langsung oleh sastrawan ternama. Fenomena lain, juga muncul dari koran, paling tidak hampir seluruh koran kini memiliki dua edisi, satu edisi cetak dan satunya lagi adalah edisi digital. Sehingga pada akhirnya batasan sastra siber sudah menjadi buyar. Hal ini karena karya sastra tersebut memiliki dua versi, versi cetak dan digital.

Namun demikian, ada sebagian penulis yang mempertahankan konsep sastra digital dengan mempublikasikan karyanya lewat media internet saja. Salah satu yang konsisten adalah laman sastradigital.com. Laman ini, menampung karya sastra baik cerpen, puisi, maupun esai sastra. Bedanya, jika sastra siber semula disebut sastra sampah, maka laman ini berusaha mengubah paradigma tersebut dengan melakukan proses kurasi yang ketat.

Dari sini, sastra siber paling tidak memiliki tiga peran dalam kesastraan Indonesia: (1) sebagai media untuk mempublikasikan karya sastra, (2) sebagai media untuk berkomunikasi antar penulis (sastrawan), dan (3) sebagai media pembelajaran untuk sastrawan pemula. Ketiga aspek ini memunculkan wajah sastra siber yang baru yang memungkinkan adanya 
penyimpangan bahasa. Penyimpangan bahasa tersebut menurut Leech terdiri memiliki sembilan ripe (1976:42-52) penyimpangan tersebut dapat berupa penyimpangan leksikal, semantis, fonologis, morfologis, sintaksis, dialek, register, historis, dan grafologis.

Penyimpangan bahasa dalam karya sastra memang bukan hal yang aneh, namun tentu saja tetap menarik untuk ditelaah dengan lebih mendalam, terlebih penyimpangan bahasa dalam sastra siber belum pernah ditelaah oleh para peneliti saat ini. Hal ini berbanding terbalik dengan penelitian kebahasaan yang telah banyak membahas fenomena kebahasaan di laman atau jejaring sosial.

Atas dasar pemikiran tersebut, maka rumusan masalah penelitian ini adalah bagaimana penyimpangan bahasa puisi dalam sastra siber? Adapun tujuan penelitian ini adalah untuk mengetahui penyimpangan bahasa puisi dalam sastra siber.

\section{Penyimpangan Bahasa}

Penyimpangan bahasa dalam karya sastra dimungkinkan. Hal ini karena karya sastra memiliki sistim linguistik yang lebih longgar dibandingkan dengan teks lainnya. Terlebih khusus dalam puisi, penyair memiliki kebebasan dalam menyampaikan pendapatnya karena ia memiliki apa yang disebut dengan licencia poetica atau kebebasan dalam berpuisi.

Pandangan semacam itu, membuatpenyair bebas menyampaikan ekspresinya. Memainkan diksi dengan patahan-patahan simbol yang jauh dari makna denotatif, juga mempermainkan enjabemen dengan membentuk tifografi tertentu sudah menjadi sesuatu yang lazim dalam puisi.

Di Indonesia, Sutarji Calzoum Bahcri bahkan menjadikan puisinya dengan pakem mantra. Membentuk tipografi dan teks puisi dengan loncatan imajinasi yang terjal. Pembaca bukan hanya disajikan permainan rima, namun juga misteri pemaknaan kata.

Fenomena melakukan penyimpangan bahasa memang merupakan kecendrungan umum penyair. Penyimpangan bahasa tersebut kemudian dirumuskan Leech Puspokusumo (2014) dalam Koesumo menjadi sembilan penyimpangan yang terdiri dari penyimpangan leksikal, semantis, fonologis, morfologis, sintaksis, dialek, register, historis, dan grafologis.

Penyimpangan yang pertama adalah penyimpangan leksikal. Disebut penyimpangan leksikaljika puisi tersebut memakai kata-kata yang menyimpang atau diselewengkan dari yang biasa kita gunakan sehari-hari hanya untuk tuntutan estetis dan memberi makna lebih dalam. Misalnya dalam puisi Dian Hartatih, ia menggunakan kata laku (perbuatan) dengan istilah baru lelaku (perbuatan yang berulang).

Penyimpangan kedua ialah penyimpangan semantis. Penyimpangan ini terlihat jika sebuah kata yang bermakna biasa dapat memiliki makna yang luar biasa. Selain itu, sebuah kata itu maknanya sangat bergantung pada siapa dan bagaimana latar belakang kehidupan dan budaya penulisnya. Misalya dalam puisi D. Zawawi Imron yang memiliki latar geografis Madura yang gersang, kata Kemarau tidak hanya menyatakan musim, namun juga telah menjadi rasa hidup.

Penyimpangan ketiga ialah penyimpangan fonologis, penyimpangan ini ialah penyimpangan bunyi yang sengaja dilakukan untuk kepentingan rima. Chairil Anwar, menggunakan kata peri untuk menggandkan kata perih.

Penyimpangan keempat ialah penyimpangan Morfologis. Penyimpangan semacam ini sering dilakukan Rendra. Ia menggunakan kata nangis untuk merujuk pada kata menangis. Dari contoh tersebut, jenis penyimpangan melihat puisi dari sudut cara pembentukan kata.

Penyimpangan kelima ialah penyimpangan sintaksis. Dalam penyimpangan ini, penyair tidak mengindahkan aturan yang harus ada dalam sebuah kalimat. Kadang-kadang antara kalimat dengan kalimat tidak memakai titik sehingga bila kita tidak cermat 
memperhatikannya, kita tidak akan mengerti kesatuan manakah yang dapat kita sebut sebagai kalimat. Panyair Indonesia yang melakukan ini ialah Sutardji Calzoum Bachri.

Penyimpangan keenam ialah penyimpangan dialek. Penyimpangan jenis ini sering ditemui dalam puisi yang ditulis oleh penyair-penyair yang ingin mengungkapkan isi hatinya dengan tuntas tapi merasa bahwa bahasa konvensional (resmis) yang ada tidak bisa mewakili apa yang dirasakannya; yang bisa mewakilinya adalah dialek daerahnya sendiri. Di antara penyair yang menggunakan penyimpangan bahasa seperti ini ialah Linus Suryadi yang menggunakan istilah Jawa, sementara dari luar Jawa, bisa dilihat pada karya Gus Tf yang menggunakan istilah Padang dan LK. Ara yang menggunakan istilah Aceh.

Penyimpangan ketujuh ialah penyimpangan Register. Penyimpangan register berkaitan dengan bahasa yang digunakan dalam sebuah kelompok atau profesi tertentu dalam masyarakat. Register disebut juga dialek profesi, biasanya hanya diketahui atau digunakan oleh segolongan atau sekelompok kecil masyarakat. Sebagai contoh dalam puisi Jamal D Rahman berjudul Rubaiyat Matahari. Istilah Rubaiyat hanya diketahui oleh orang-orang sufi.

Penyimpangan kedelapan ialah penyimpangan Historis.Penyimpangan historis merupakan penyimpangan yang berbentuk penggunaan kata-kata kuno yang sudah tidak dipakai lagi dalam kehidupan sehari-hari. Deviasi ini tujuannya untuk mempertinggi nilai estetis sebuah puisi.

Penyimpangan kesembilan ialah penyimpangan grafologis. Jenis penyimpangan ini terletak pada cara penulisan kata, kalimat, larik, dan baris. Penyair dengan sengaja menulisnya tanpa mengindahkan kaidah yang berlaku. Hal ini dipergunakan untuk memperoleh estetik. Salah satu penyair yang sering melakukan ini adalah Sutarji Calzoum Bachri yang banyak dilakukannya dalam kumpulan puisinya 0 , Amuk, Kapak.

\section{Puisi}

Puisi selalu identik dengan kata indah, hal inilah yang menjadi dasar mengapa sebuah puisi berbeda dengan karya sastra lainnya. Sebetulnya keindahan sebuah puisi bukan semata-mata untuk mendapatkan kesan estetik belaka, namun dibalik susunan makna tersebut, tertuang spirit untuk berbagi, untuk menyadarkan pembaca, untuk melekatkan suatu peristiwa sehingga pembaca mampu mengambil hikmahnya. Oleh karena itu, Pradopo (1987: 7) berpendapat,

Puisi itu mengeksperesikan pemikiran yang membangkitkan perasaan, yang merangsang imajinasi panca indra dalam susunan yang bairirama. Semua itu merupakan sesuatu yang penting, yang direkam dan diekspresikan, dinyatakan dengan menarik dan memberi kesan. Puisi itu merupakan rekaman dan interprestasi pengalaman manusia yang penting, di ubah dalam wujud yang paling berkesan.

Pendapat tersebut paling tidak memunculkan suatu pandangan bahwa, memang keindahan sengaja dihadirkan agar memberikan kesan yang paling dalam kepada pembacanya. Oleh karena itu, sebuah puisi memiliki beban bukan hanya makna tapi juga keindahan.

Bagaimana sebuah puisi membangun keindahan? Sebetulnya keindahan dapat lahir dari bagaimana puisi itu mampu mengembangkan imajinasi pembaca. Puisi yang penuh dengan metafor, lambang, dan irama yang kuat akan membuat pembaca menikmati, menafsir dan menambil hikmahnya. Oleh karena itu Pradopo menyebut sebagai merangsang imajinasi. Hal ini pula sebetulnya yang disampaikan oleh Sarumpaet (2002: 2) bahwa puisi dibangun dengan susunan kata yang kaya akan imaji.

Tak jauh berbeda dengan Sarumpaet, Waluyo (1987: 25) menyampaikan bahwa, "Puisi adalah bentuk karya sastra yang mengungkapkan pemikiran dan perasaan penyair secara imajinadf dan disusun dengah pengkonsentrasian semua kekuatan bahasa 
dengan pengkonsentrasian struktur fisik dan struktur batin"

Dari pendapat tersebut, selain merujuk pada pengembangan imajinadf, Waluyo juga menekankan bahwa kata imajinadf dalam puisi dibangun oleh dua struktur puisi, yakni struktur fisik dan struktur batin. Selain itu, sejatinya sebuah puisi tidak dilahirkan hanya melalui proses kebahasan, namun lebih dari itu, puisi dilahirkan untuk kebermaknaannya di tengah pembaca. Oleh karena itu, dengan dua struktur ini, seorang pembaca puisi akan menangkap keindahan sekaligus makna.

Adapun yang dimaksud dengan unsur fisik dan unsur batin, disebut Waluyo (1987:28) sebagai berikut, "Struktur batin puisi terdiri dari: tema, nada, perasaan,dan amanat, sedangkan struktur fisik puisi terdiri atas: diksi, pengimajian, kata konkret, majas, verifikasi, dan tipografi puisi."

\section{Sastra Siber}

Perkembangan teknologi memunculkan trend kehidupan yang baru. Pola komunikasi mengalami perubahan yang ekstrim. Untuk bertatap muka, kini tidak harus bertemu di suatu rempat. Dengan kecanggihan teknologi, bertatap muka dapat dilakukan hanya dengan terkoneksi internet.

Tentu akses yang mudah ini memunculkan berbagai macam hal baru termasuk di dalamnya tentang sastra. Dengan adanya teknologi, penyair dapat menyajikan puisinya kepada banyak orang tanpa harus dimuat di media massa. Penyair dapat mengunggah karyakaryanya di laman buatannya. Hal inilah yang memutuskan jarak antara penyair dan pembacanya dengan cara yang lebih singkat dan mudah. Bahkan penyair dapat menyasar sendiri pembacanya secara lebih khusus jika ia mempublikasikannya di jejaring sosial seperti facebook dan twitter.

Fenomena inilah yang kemudian memunculkan istilah sastra siber. Sastra siber menurut Endraswara merupakan aktivitas sastra yang memanfaatkan media komputer atau internet (2006:182). Dari pola pemanfaatan internet ini, sastra siber dikenal juga sebagai sastra digital.

Dengan kemudahan yang disajikan dalam sastra siber, maka kemudian memunculkan dampak positif dan negatif. Positifnya, karya sastra dapat disajikan dengan mudah kepada masyarakat dan masyarakat mampu mengaksesnya dengan sangat mudah selama terkoneksi dengan internet. Dampak negatifnya, kemudahan mengunggah karya sastra memunculkan perbedaan kualitas yang selama ini dijaga dalam media massa. Masyarakat umum kemudian akan dibingungkan dengan kualitas mana yang baik. $\mathrm{Hal}$ ini mengingat, siapapun bisa mengunggah puisi ke laman yang dibuatnya.

\section{METODE}

Untuk mengetahui bagaimana penyimpangan bahasa puisi dalam sastra siber, penulis menggunakan metode deskriptif analisis. Fokus penelitian ini ialah pada penyimpangan bahasa puisi yang terdapat dalam sastra siber. Untuk membatasi wilayah sastra siber, maka penulis mengambil sampel puisi dari laman sastradigital. com sebanyak 5 puisi yang dipilih secara acak dari bulan Maret-Desember 2013. Puisi tersebut ialah Kidung Rindu Bagi Perempuanku karya Alif Raung Firdaus, Aek Sarulla karya Mangasi Sihombing, Mimpi dari Milimeter Jarak Sepi karya Ujianto Sadewa, Bukan Kopi Hongaria karya Cecep Samsul Hari, dan Di Jembatan Pasupati karya Fajar M. Fitrah. Adapun instrumen dalam penelitian ini ialah peneliti dan tabel kerja analisis penyimpangan bahasa puisi dalam sastra siber.

\section{PEMBAHASAN}

\section{Puisi Kidung Rindu Bagi Perempuanku}

Kidung Rindu Bagi Perempuanku

Dalam tubuh malam, aku berlayar Lautnya berombak rembulan keteduhan Di atas biduk, kudendangkan lagu kerinduan 
Duhai, perempuanku, telah berjamjam kau berlalu

Membagi kesepian yang dada bertalu

Bila matahari telah singsing, di esok senja yang dingin

Aku telah menemuimu dengan dekap dan peluk

Begitu katamu, pada suatu pagi yang teramat asing

Demikianlah, malam ini aku mengakrabi kesunyian

Di antara deru jalanan yang gaduh, angin yang gemuruh

Sisa-sisa hujan tadi sore yang membikin tanah basah-resah

Dan betapa sungguh secangkir kopi yang kuseruput

Menjadi tawar, menjadi hambar, disesaki ingatan pekat

Dan bau tubuhmu yang senantiasa terus melekat

Dalam tubuh malam, aku terus berlayar

Lautnya berombak rembulan keteduhan

Di atas biduk, kudendangkan lagu

kesepian

Duhai, perempuanku, dari sekian banyak ketakutanku

Yakinlah kalau aku tak mampu melupakanmu

Jember, 06 Oktober 2012

Puisi Alif di atas melakukan tiga penyimpangan bahasa yakni penyimpangan sintaksis, penyimpangan historis, dan penyimpangan morfologis. Penyimpangan sintaksis secara keseluruhan terlihat pada tidak adanya tanda titik dalam puisi berjudul Kidung Rindu Bagi Perempuanku. Meski pada bait keempat Alif melakukan kembali penyimpangan sintaksis dengan meletakkan kata dan pada awal baris puisi. Jika dilihat bentuknya yang ditulis kapital, maka bisa ditafsirkan bahwa setiap baris adalah awal kalimat, maka dan pada puisi tersebut telah melakukan penyimpangan sintaksis.

Adapun penyimpangan historis terlihat pada bait kedua dalam puisi ini, Alif menggunakan kata dubai yang kini tidak lazim digunakan. Sehingga dapat dikatakan apa yang dilakukan Alif ini adalah penyimpangan historis.

Untuk penyimpangan leksikal terlihat pada bait kedua pula, bagaimana pengulangan kata tidak ditulis sebagaimana mestinya, yakni berjamjam. Tidak adanya tanda pemisah ketika melakukan pengulangan kata, menjadi tanda bahwa puisi ini telah melakukan penyimpangan leksikal.

\section{Puisi Aek Sarulla}

\section{Aek Sarulla}

Sahabat, kuingin sajikan pelipur lara

Membasuh ratap dan luka hati,

Karna di depan waktu terentang

Dan hentakan perjalanan masih panjang.

Sahabat, lupa tak bisa, otak terus berjaga, Asal hiburanmu tak menambah nestapa.

Untukmu lagu harapan,

Penyejuk hati penyegar pikiran:

"Aek Sarulla, Aek Sarulla kemana kau pergi?

Jalanmu panjang nian, sudi bisikkan padaku

Yang kau lihat dan alami sepanjang hari.

Kuharap beritamu menyenangkan hati".

Wah sejuk, sejuk nian itu madah.

Kutahu Aek Sarulla,

Kecil, mungil lagi cantik.

Beritanya ke pelosok dunia,

Rindu memandangnya sejak lahirnya,

Karena bisikannya hanya damai

Seperti aku, nenek dari neneknya.

Oh cicit dari cicitku,

Air nan indah dan damai 
Semoga ceritamu selalu indah seperti namamu.

Puisi karya Mangasi ini melakukan dua penyimpangan bahasa. Penyimpangan tersebut terdiri dari penyimpangan dialek dan historis. Penyimpangan bahasa pertama adalah penyimpangan dialek. Pada puisi ini dialek terlihat menjadi jantung inspirasi bagi karya Mangasi ini. Hal ini terlihat bagaimana kata Aek Sarulla menjadi judul puisi ini. Aek Sarulla merupakan lagu rakyat Batak yang berarti Sungai Sarulla.

Penyimpangan yang kedua ialah penyimpangan historis. Penyimpangan ini terlihat pada tiga kata yang digunakan. Masingmasing terdapat pada bait keempat dan kelima. Pada bait keempat di baris pertama terdapat dua kata nian dan madah yang merupakan bahasa yang sudah jarang digunakan. Sementara dibait kelima terlihat pada baris keempat kata nanyzng juga sudah jarang digunakan. Oleh karena itu, puisi karya Mangasi ini dapat disebut melakukan penyimpangan historis.

\section{Puisi Mimpi dari Milimeter Jarak Sepi}

\section{Mimpi dari Milimeter Jarak Sepi}

Membuat mimpi yang serupa jaring laba-laba

Adalah kertas gambar menghitam

Waktu memadat serupa jarak tak tertahan

Saat itu melihat langit adalah versi lain

Dari banyak kegembiraan yang lain

Hati yang ini masih sama

Kristalnya tetap nyala bening

Di antara ranting patah, daun kering

Dan matamu yang redup

Perasaan ini kini berkabut

Seperti milimeter jarak mimpi

Yang diciptakan lagi dari ingatan

Puisi karya Ujianto ini melakukan dua penyimpangan bahasa. Penyimpangan itu terdiri dari penyimpangan sintaksis dan semantis. Untuk penyimpangan sintaksis dapat dilihat dari tidak adanya tanda titik dalam puisi ini meskipun puisi ini beberapa kali menggunakan tanda baca koma. Selain itu, terlihat pula dalam bait kedua baris keempat, Ujianto meletakkan kata dan di awal baris. Jika diasumsikan kata tersebut awal kalimat karena huruf pertamanya ditulis kapital, maka apa yang dilakukan Ujianto adalah sebuah penyimpangan sintaksis.

Adapun penyimpangan semantis terlihat pada kata berkabut pada baris puisi Perasaan ini kini berkabut. Kata tersebut memiliki makna simbolik yang tentu bukan makna harliah karena tidak ada perasaan yang di dalamnya ada kabut. Kabut di sini bisa menyiratkan keraguan, kegundahan, dan bisa jadi kerinduan yang tak terpenuhi. Oleh karena itu, dapat dikatakan Ujianto telah melakukan penyimpangan semantis.

\section{Puisi Bukan Kopi Hongaria}

\section{Bukan Kopi Hongaria}

Cecep, di mana kau tinggalkan sopan santunmu begitu berani kau memesan kopi Irlandia di negeri kelahiran Jozsef Attila?

Seamus bertanya dengan sungging senyum jenaka

dan pelan dihirupnya teh Earl-Grey panas itu dengan gaya anggun seorang bangsawan yang seumur hidup tinggal di istana Buckingham.

Telah dua abad kusimpan tubuh lelakiku di dalam kulkas

beku Balaton. Katakan kepadaku, adakah yang lebih sedap

di senja es batu ini selain semangkuk kecupan, sekeranjang pelukan, dihidangkan di atas nampan hangat tubuh mentega perempuan Babylon?

Cecep, di mana kau tinggalkan sopan santunmu memalingkan wajah dari pelayan berparas dewi itu

dan menyanjung jalang kehancuran Iskandar yang agung. 
Seamus mengusir debu cerutu dari licin lengan jas

yang dijahit di utara Belfast. Kabut di matanya seperti asap mesiu masa silam perang saudara yang telah membelah dua negeri abadi cintanya.

Cecep, aku berkata kepada diriku sendiri sejauh langit kau pergi mengembara dan meskipun kau berjalan sepanjang cakrawala tidak akan pernah kau temukan dalam jiwamu nafas Hasan al-Wazan atau Leo dari Afrika.

Balatonfured, 2009

Puisi karya Cecep ini melakukan dua penyimpangan bahasa yang terdiri dari penyimpangan semantis dan penyimpangan dialek. Namun di antar dua penyimpangan bahasa tersebut, maka penyimpangan semantis yang paling dominan.

Penyimpangan semantis yang dilakukan Cecep pada bait ketiga puisi ini. Di bait ini ada tiga kata yang telah melakukan pergeseran makna yang sangat jauh, kata kulkas, semangkuk, sekeranjang, dan mentega. Kata pertama yakni Kulkas yang terdapat pada baris puisi Telah dua abad kusimpan tubuh lelakiku di dalam kulkas. Kata kulkas merupakan simbol dari suatu perasaan yang sangat kompleks, dapat bermakna hati yang beku atau bisa jadi kebosanan. Kata lain adalah semangkuk kecupan, sekeranjang pelukan serta mentega perempuan yang jika menilik bait puisi ini berpusat pada kata dihidangkan. Sehingga kata semangkuk, sekeranjang, dan mentega, adalah ungkapan metaforis dari sajian syahwat yang diberikan di musim dingin.

\section{Puisi Di Jembatan Pasupati}

\section{Di Jembatan Pasupati}

jika di sini aku berbagi kopi dengan plato aku tak lagi amini pengemudi rusuh selalu banyak musuh tapi

di jembatan layang yang

membelah makam-

makam karuhun dan

angin pasundan ini aku

hanya sendiri

mencari-cari arah

datang waktu

2013

Dalam puisi karya Fajar ini terdapat empat penyimpangan bahasa. Penyimpangan bahasa tersebut terdiri dari penyimpangan sintaksis, penyimpangan grafologis, penyimpangan register, dan penyimpangan dialek.

Penyimpangan sintaksis yang dilakukan Fajar dalam puisinya ini terlihat tidak adanya tanda baca dalam puisi ini. Baik koma, tanda titik, atau bahkan tanda seru dan tanya. Selain itu, jika merujuk pada enjabemen dalam ketiga bait puisi Fajar ini terasa kurang tepat, misalnya dibait pertama pemenggalan itu dilakukan dengan asal: aku berbagi kopil dengan plato, padahal ada kemungkinan baginya untuk menuliskannya dalam satu baris. Hal ini dirasa kurang tepat lantaran membuyarkan struktur sintaksis bahasa. Oleh karena itu, dapat disebut pula apa yang dilakukan Fajar ini sebagai penyimpangan sintaksis.

Untuk penyimpangan grafologis terlihat pada bagaimana bentuk puisi ini melakukan enjabemen dengan seenaknya. Fajar tidak memperhatikan pemenggalan bait yang baik atau bahkan memang melakukan hal tersebut untuk menyiratkan pesan secara kuat. Oleh karena itu, usaha yang dilakukan Fajar ini dapat disebut sebagai penyimpangan grafologois.

Selain dua penyimpangan tersebut, Fajar melakukan penyimpangan register. Penyimpangan ini terlihat pada baris puisi aku tak lagi amini. Kata amini dalam puisi tersebut menyiratkan kelas sosial tertentu yakni bahasa 
agamawan. Hal ini karena kata amin, merupakan sesuatu yang lazim disampaikan dalam suatu ritual ibadah.

Penyimpangan lain yang dilakukan Fajar adalah penyimpangan dialek. Penyimpangan ini terlihat pada bait kedua baris keempat, kata karuhun digunakan Fajar untuk menyampaikan maksud puisinya yang barangkali tak dapat disampaikan kecuali dengan menggunakan bahasa dialeknya.

\section{SIMPULAN}

Penyimpangan bahasa merupakan sesuatu yang tidak dapat dihindarkan oleh seorang penyair. Penyimpangan dilakukan untuk menciptakan efek estetis yang memang harus dibangun di dalam sebuah puisi. Hal ini pula yang terjadi dalam lima puisi yang diunggah di laman sastradigital.com. Kelima puisi tersebut memang melakukan penyimpangan bahasa.

Dalam puisi Kidung Rindu Bagi Perempuanku karya Alif Raung Firdaus penyimpangan bahasa yang dilakukan hanya pada penyimpangan penyimpangan sintaksis, penyimpangan historis, dan penyimpangan leksikal. Dalam pxnsi Aek Sarulla karya Mangasi Sihombing penyimpangan bahasa yang dilakukan adalah penyimpangan dialek dan penyimpangan historis. Dalam puisi Mimpi dari Milimeter Jarak Sepi karya Ujianto Sadewa penyimpangan bahasa yang dilakukan adalah penyimpangan sintaksis dan penyimpangan semantis. Dalam puisi Bukan Kopi Hongaria karya Cecep Samsul Hari penyimpangan bahasa yang dilakukan adalah penyimpangan semantis dan penyimpangan dialek. Adapun pada puisi terakhir, yakni Di Jembatan Pasupati karya Fajar M. Fitrah penyimpangan bahasa yang dilakukan adalah penyimpangan sintaksis, penyimpangan grafologis, penyimpangan register, dan penyimpangan dialek.

Dengan demikian, dari pemaparan di atas, maka terlihat bahwa dari sembilan penyimpangan bahasa, maka hanya ada tujuh penyimpangan bahasa. Penyimpangan itu terdiri dari leksikal, semantis, sintaksis, dialek, register, historis, dan grafologis. Adapun yang tidak terdapat dalam lima puisi tersebut ialah penyimpangan fonologis dan penyimpangan morfologis.

\section{DAFTAR PUSTAKA}

Firdaus, Alif Raung. 2014. "Kidung Rindu Bagi Perempuanku." Diunduh dari http:// sastradigital.com pada 12 Mei 2014.

Fitrah, Fajar M. 2014. "Di Jembatan Pasupati." Diunduh dari http://sastradigital.com pada 12 Mei 2014.

Hari, Cecep Samsul. 2014. "Bukan Kopi Hongaria." Diunduh dari http:// sastradigital.com pada 12 Mei 2014.

Pradopo, Rahmatjoko. 1987. PengkajianPuisi. Yogyakarta: Gajah Mada University Press.

Puspokusumo, Kanya. 2014. "Deviasi Konvensi Linguistik Dalam Puisi." Diunduh dari http:// doeniadevi.wordpress.com/2009/10/20 / deviasi-konvensi-linguistik-dalam-puisi/ pada 8 Mei 2014.

Sadewa, Ujianto. 2014. "Mimpi dari Milimeter Jarak Sepi." Diunduh dari http:// sastradigital.com pada 12 Mei 2014.

Sarumpaet, Riris K. Toha. 2002. Apresisi Puisi Remaja. Jakarta: PT Grasindo.

Sihombing, Mangasi. 2014. "Aek Sarulla. "Diunduh dari http://sastradigital.com pada 12 Mei 2014. Suwardi. 2006. Metodologi Penelitian Sastra,

Epistemologi, Model, Teori dan Aplikasi. Yogyakarta: Pustaka Widyatama.

Waluyo, Herman J. 1987. Teori dan Apresiasi Puisi. Jakarta: Erlangga. 